\title{
FAKTOR-FAKTOR YANG MEMPENGARUHI PERAN SERTA KADER POSYANDU DALAM DETEKSI DINI RISIKO TINGGI KEHAMILAN DI WILAYAH KERJA PUSKESMAS WARUNGGUNUNG TAHUN 2016
}

\author{
*Nurul Misbah, *Ayi Tansah R.
}

\begin{abstract}
Abstrak
Peranan kader sangat penting karena kader ikut bertanggung jawab dalam pelaksanaan program Posyandu. Bila kader tidak aktif maka pelaksanaan posyandu juga akan menjadi tidak lancar dan akibatnya pelayanan di posyandu akan terhambat yang berdampak pada cakupan kunjungan ibu dan bayi/balita. Keikutsertaan dan keaktifan kader di posyandu diharapkan mampu menggerakkan partisipasi masyarakat. Karena Kader merupakan titik sentral dalam pelaksanaan kegiatan posyandu. Namun keberadaan kader relatif labil karena partisipasinya bersifat sukarela sehingga tidak ada jaminan untuk tetap menjalankan fungsinya dengan baik seperti yang diharapkan. Tujuan Penelitian ini adalah untuk mengetahui faktor-faktor apa saja yang mempengaruhi peran serta kader posyandu dalam deteksi dini risiko kehamilan di wilayah Kerja Puskesmas Warunggunung Kabupaten Lebak Tahun 2016. Desain penelitian deskriptif analitik dengan mengunakan pendekatan cross sectional. Jumlah Populasi berjumlah 270 orang sedangkan sampel pada penelitian ini adalah kader posyandu di wilayah kerja Puskesmas Warunggunung sebanyak 75 orang, Analisis data dilakukan dengan analisis univariat dan analisis bivariat.

Hasil penelitian menunjukan Masih ada sebagian kecil peran serta kader posyandu kurang $(26,7 \%)$, hampir setengahnya pengetahuan kader posyandu kurang $(45,3)$, sebagian besar kader posyandu tingkat pendidikannya rendah $(65,3 \%)$, sebagian kecil kader posyandu tidak pernah mengikuti pelatihan kader $(30,7 \%)$, masih terdapat kader posyandu bersikap negatif terhadap deteksi dini pada kehamilan ( 32,0\%), hampir setengahnya kader posyandu pengalaman menjadi kader $<10$ tahun $(48,0 \%)$, terdapat hubungan antara pengetahuan, sikap dan riwayat pelatihan dengan peran kader Posyandu di Kecamatan Warunggunung. Tidak terdapat hubungan antara, Pendidikan dan Pengalaman dengan Peran Kader Posyandu di Kecamatan Warunggunung.

Puskesmas khususnya bidan desa hendaknya meningkatkan kegiatan pelatihan dan pembinaan kepada kader-kader posyandu terkait deteksi dini resiko tinggi pada ibu hamil secara periodik.
\end{abstract}

Daftar Pustaka (18: 2002-2014)

*) Dosen Jurusan Kebidanan Poltekkes Kemenkes Banten 


\section{Pendahuluan}

Angka Kematian Ibu (AKI) sampai saat ini masih menjadi perhatian utama pemerintah, baik pada pemerintah pusat maupun daerah. AKI merupakan indikator keberhasilan pembangunan suatu bangsa, semakin baik pembangunan selaras dengan semakin kecil AKI. Akan tetapi berbagai upaya yang telah dijalankan hingga saat ini belum menunjukkan hasil yang memuaskan, meski AKI sempat menurun hingga 228/100.000 Kelahiran Hidup (KH) (SDKI, 2007) namun berdasarkan hasil survey terakhir AKI meningkat lagi mencapai 359/100.000 KH (SDKI, 2012).

Penyebab langsung kematian ibu adalah pendarahan 28\%, eklamsi $24 \%$,infeksi $11 \%$, partus lama 5\%, abortus 5\%, dan lain-lain (SKRT 2001). Sedangkan penyebab tidak langsung kematian ibu karena kondisi masyarakat seperti pendidikan, sosial ekonomi dan budaya. Kondisi geografi serta keadaan sarana pelayanan yang kurang siap ikut memperberat permasalahan ini. Kondisi tersebut mengakibatkan 3 terlambat (terlambat mengambil keputusan, terlambat sampai di tempat pelayanan dan terlambat mendapatkan pertolongan yang adekuat) dan 4 terlalu (terlalutua, terlalu muda, terlalu banyak, terlalu rapat jarak kelahiran).

Salah satu upaya untuk menurunkan angka kematian ibu (AKI) dan janin adalah dengan cara peningkatan pemanfaatan fasilitas kesehatan oleh masyarakat, yang dimulai dari pelayanan antenatal dengan pengenalan adanya risiko tinggi ibu hamil yang dilakukan melalui skrining atau deteksi dini. Adanya faktor risiko secara pro aktif pada semua ibu hamil, hal ini dilakukan sedini mungkin pada awal kehamilan oleh petugas kesehatan atau non kesehatan yang terlatih di masyarakat, misalnya kader kesehatan, ibu-ibu PKK, Karang Taruna, ibu hamil sendiri, suami atau keluarga. Kegiatan skrining antenatal, melalui kunjungan rumah merupakan langkah awal dari pemeliharaan kesehatan ibu hamil. (Dian, 2007).

Berdasarkan hasil observasi peneliti di lapangan bahwa pelaksanaan kegiatan posyandu yang dilakukan oleh kader berdasarkan pelaksanaan sistim 5 meja, tidak berjalan dengan semestinya. Pelaksanaannya hanya sebatas pada meja II (penimbangan) dan meja III (pencatatan di KMS). Penyuluhan yang seharusnya diberikan oleh kader, pada kenyataannya di lapangan sebagian besar kader masih sangat bergantung pada petugas kesehatan. Kader hanya melakukan penimbangan pada balita dan jika ada timbangan yang kurang atau lebih kader tidak memberikan penyuluhan kesehatan kepada ibu-ibu yang membawa balitanya. Hal yang dianggap paling sulit oleh kader adalah mendeteksi adanya faktor risiko sedini mungkin pada awal kehamilan 
dan memberikan penyuluhan tentang tanda bahaya pada ibu hamil (Sugeng, 2008).

Dari hasil studi pendahuluan yang diperoleh dari Puskesmas Warungunung ditemukan bahwa dari 160 orang Ibu hamil dengan resiko tinggi yang terdeteksi oleh masyarakat (kader Posyandu) hanya 35 orang (27,3\%) sedangkan Deteksi Resti oleh tenaga kesehatan mencapai 125 orang (97,7\%). Begitu pula dari hasil studi pendahuluan pada 10 orang kader, ditemukan bahwa hanya 3 orang yang melakukan skrining atau deteksi dini resiko tinggi pada ibu hamil.

\section{Metoda Penelitian}

Desain penelitian yang digunakan adalah survei analitik dengan menggunakan pendekatan cross sectional, karena dalam penelitian ini ingin diperoleh faktor-faktor yang mempengaruhi Peran serta Kader Posyandu dalam deteksi risiko kehamilan. Model pendekatan atau observasi sekaligus pada satu saat (point time approach), tiap subyek hanya diobservasi sekali saja. Populasi penelitian ini adalah semua Kader Posyandu di Wilayah Kerja Puskesmas Warunggunung Kabupaten Lebak Provinsi Banten, berjumlah 270 orang.

Sampel penelitian ini adalah sebagian dari seluruh kader kesehatan yang berada di wilayah kerja Puskesmas Warunggunung yang berjumlah 75 orang

\section{Hasil}

1. Analisis Univariat

Tabel 1

Distribusi Frekuensi Peran Serta Kader

Posyandu di Kecamatan Warunggunung Tahun 2016

\begin{tabular}{lcc}
\hline $\begin{array}{l}\text { Peran Serta } \\
\text { Kader }\end{array}$ & Frekuensi & Persentase \\
\hline Kurang & 20 & 26,7 \\
Baik & 55 & 73,3 \\
\hline Jumlah & 75 & 100 \\
\hline
\end{tabular}

Pada tabel diatas menunjukkan bahwa masih ada sebagian kecil Peran Serta Kader Posyandu kurang (26,7\%)

Tabel 2

Distribusi Frekuensi Kader Posyandu berdasarkan Pengetahuan di Kecamatan Warunggunung Tahun 2016

\begin{tabular}{lcc}
\hline Pengetahuan & Frekuensi & Persentase \\
\hline Kurang & 35 & 46,7 \\
Baik & 40 & 53,3 \\
\hline Jumlah & 75 & 100 \\
\hline
\end{tabular}

Dari tabel diatas menunjukkan bahwa hampir setengahnya Pengetahuan Kader Posyandu kurang $(46,7)$

Tabel 3

Distribusi Frekuensi Kader Posyandu berdasarkan Pendidikan di Kecamatan Warunggunung Tahun 2016

\begin{tabular}{lcc}
\hline Pendidikan & Frekuensi & Persentase \\
\hline Rendah & 49 & 65,3 \\
Tinggi & 26 & 34,7 \\
\hline Jumlah & 75 & 100 \\
\hline
\end{tabular}

Dari tabel diatas menunjukkan bahwa sebagian besar kader posyandu tingkat pendidikannya rendah $(65,3 \%)$ 
Tabel 4

Distribusi Frekuensi Kader Posyandu berdasarkan Riwayat Pelatihan di Kecamatan Warunggunung Tahun 2016

\begin{tabular}{lcc}
\hline $\begin{array}{l}\text { Riwayat } \\
\text { Pelatihan }\end{array}$ & Frekuensi & Persentase \\
\hline Tidak Pernah & 34 & 45,3 \\
Pernah & 41 & 54,7 \\
\hline Jumlah & 75 & 100 \\
\hline
\end{tabular}

Dari tabel diatas menunjukkan bahwa hampir setengahnya kader posyandu tidak pernah mengikuti pelatihan kader $(45,3 \%)$

\section{Tabel 5}

Distribusi Frekuensi Kader Posyandu berdasarkan Sikap di Kecamatan Warunggunung tahun 2016

\begin{tabular}{lcc}
\hline Sikap & Frekuensi & Persentase \\
\hline Negatif & 24 & 32,0 \\
Positif & 51 & 68,0 \\
\hline Jumlah & 75 & 100 \\
\hline
\end{tabular}

Dari tabel diatas menunjukkan bahwa masih terdapat kader posyandu bersikap negatif terhadap deteksi dini pada kehamilan $(32,0 \%)$.

Tabel 6

Distribusi Frekuensi Kader Posyandu berdasarkan Pengalaman di Kecamatan Warunggunung tahun 2016

\begin{tabular}{lcc}
\hline Pengalaman & Frekuensi & Persentase \\
\hline$<10$ tahun & 36 & 48,0 \\
$\geq 10$ tahun & 39 & 52,0 \\
\hline Jumlah & 75 & 100 \\
\hline
\end{tabular}

Dari tabel diatas menunjukkan bahwa hampir setengahnya kader posyandu Pengalaman menjadi kader $<10$ tahun $(48,0 \%)$.

\section{Analisis Bivariat}

Tabel 7

Hubungan Pengetahuan dengan Peran Kader Posyandu di Kecamatan Warunggunung Tahun 2016

\begin{tabular}{lccccc}
\hline \multirow{2}{*}{ Pengetahuan } & \multicolumn{2}{c}{ Peran } & Jumlah & P & OR \\
& Negatif & Positif & & Value & \\
\hline Kurang & 14 & 21 & 34 & & \\
& $(40,0 \%)$ & $(60,0 \%)$ & $(100 \%)$ & & 3,778 \\
\multirow{2}{*}{ Baik } & 6 & 34 & 41 & 0,015 & $(1,257-$ \\
& $(15,0 \%)$ & $(85,0 \%)$ & $(100 \%)$ & & $11,352)$ \\
\cline { 1 - 4 } Jumlah & 20 & 55 & 75 & & \\
& $(26,7 \%)$ & $(73.3 \%)$ & $(100 \%)$ & & \\
\hline
\end{tabular}

Dari tabel diatas menunjukkan bahwa kader yang memiliki peran negatif proporsinya lebih besar pada kader yang memiliki pengetahuan kurang (40,0\%), dibandingkan kader yang memiliki pengetahuan baik $(15,0 \%)$.

Hasil uji ststistik dengan menggunakan chi square pada alpha 0,05 diperoleh nilai $0,015(\mathrm{p}>\alpha)$, yang berarti bahwa secara ststistik ada hubungan yang signifikan antara Pengetahuan dengan Peran Kader Posyandu di Kecamatan Warunggunung. Dengan nilai OR 3,77 yang berarti bahwa kader yang memiliki pengetahuan kurang berisiko hampir 4 kali memiliki peran yang kurang sebagai kader posyandu, dibandingkan dengan kader yang pengetahuannya baik. 
Tabel 8

Hubungan Pendidikan dengan Peran Kader Posyandu di Kecamatan Warunggunung

Tahun 2016

\begin{tabular}{lcccc}
\hline \multirow{2}{*}{ Pendidikan } & \multicolumn{2}{c}{ Peran } & & P \\
& & & & \\
& & & & Value \\
\hline Rendah & 11 & 38 & 49 & \\
& $(22,4 \%)$ & $(77,6 \%)$ & $(100 \%)$ & \\
\multirow{2}{*}{ Tinggi } & 9 & 17 & 26 & \multirow{2}{*}{0,257} \\
\cline { 1 - 4 } Jumlah & $(34,6 \%)$ & $(65,4 \%)$ & $(100 \%)$ & \\
& 20 & 55 & 75 & \\
\hline
\end{tabular}

Dari tabel diatas menunjukkan kader yang memiliki peran negatif proporsinya lebih besar pada kader yang berpendidikan tinggi $(34,6 \%)$ dibandingkan kader yang memiliki pendidikan rendah $(22,4 \%)$.

Hasil uji ststistik dengan menggunakan chi square pada alpha 0,05 diperoleh nilai $0,257(\mathrm{p}>\alpha)$, yang berarti bahwa secara ststistik tidak ada hubungan yang signifikan antara Pendidikan dengan Peran Kader Posyandu di Kecamatan Warunggunung.

Tabel 9

Hubungan Riwayat Pelatihan dengan Peran Kader Posyandu di Kecamatan Warunggunung Tahun 2016

\begin{tabular}{|c|c|c|c|c|c|}
\hline \multirow{2}{*}{$\begin{array}{l}\text { Riwayat } \\
\text { Pelatihan }\end{array}$} & \multicolumn{2}{|c|}{ Peran } & \multirow{2}{*}{ Jumlah } & \multirow{2}{*}{$\begin{array}{c}\mathrm{P} \\
\text { Value }\end{array}$} & \multirow{2}{*}{ OR } \\
\hline & Negatif & Positif & & & \\
\hline $\begin{array}{l}\text { Tidak } \\
\text { pernah }\end{array}$ & $\begin{array}{c}12 \\
(52,2 \%)\end{array}$ & $\begin{array}{c}11 \\
(47,8 \%)\end{array}$ & $\begin{array}{c}23 \\
(100 \%)\end{array}$ & \multirow{3}{*}{0,001} & \multirow{3}{*}{$\begin{array}{r}6,000 \\
(1,973- \\
18,245)\end{array}$} \\
\hline Pernah & $\begin{array}{c}8 \\
(15,4 \%) \\
\end{array}$ & $\begin{array}{c}44 \\
(84,6 \%) \\
\end{array}$ & $\begin{array}{c}52 \\
(100 \%)\end{array}$ & & \\
\hline Jumlah & $\begin{array}{c}20 \\
(26,7 \%)\end{array}$ & $\begin{array}{c}55 \\
(73.3 \%)\end{array}$ & $\begin{array}{c}75 \\
(100 \%)\end{array}$ & & \\
\hline
\end{tabular}

Dari tabel 5.9 diatas menunjukkan bahwa kader yang memiliki peran negatif proporsinya lebih besar pada pada kader yang tidak pernah pelatihan $(52,2 \%)$, dibandingkan kader yang pernah mengikuti pelatihan $(15,4 \%)$.

Hasil uji ststistik dengan menggunakan chi square pada alpha 0,05 diperoleh nilai $0,001(\mathrm{p}<\alpha)$, yang berarti bahwa secara ststistik ada hubungan yang signifikan antara Pelatihan dengan Peran Kader Posyandu di Kecamatan Warunggunung. Dan nilai OR didapatkan, 6,000, dapat diartikan bahwa kader yang tidak pernah mengikuti pelatihan memiliki peran yang kurang (negatif) 6 kali lebih besar dibandingkan dengan kader yang pernah mengikuti pelatihan.

Tabel 4.10

Hubungan Sikap dengan Peran Kader Posyandudi Kecamatan Warunggunung Tahun 2016

\begin{tabular}{lcccccc}
\hline \multirow{2}{*}{ Sikap } & \multicolumn{2}{c}{ Peran } & \multirow{2}{*}{ Jumlah } & P & \multirow{2}{*}{ OR } \\
& Negatif & Positif & & & Value & \\
\hline \multirow{2}{*}{ Kurang } & 12 & 12 & 22 & & \multirow{2}{*}{5,375} \\
\multirow{2}{*}{ Baik } & $(50,0 \%)$ & $(50,0 \%)$ & $(100 \%)$ & & $(1,789$ \\
& 8 & 43 & 52 & \multirow{2}{*}{0,002} & - \\
\cline { 1 - 3 } Jumlah & $(15,7 \%)$ & $(84,3 \%)$ & $(100 \%)$ & & 16,14 \\
& $(26,7 \%)$ & $(73.3 \%)$ & $(100 \%)$ & & $6)$ \\
\hline
\end{tabular}

Dari tabel 4.10 diatas menunjukkan

kader yang memiliki peran negatif proporsinya lebih besar pada kader yang memiliki sikap kurang (50,0\%) dibandingkan kader yang memiliki sikap yang baik $(15,7 \%)$.

Hasil uji ststistik dengan menggunakan chi square pada alpha 0,05 diperoleh nilai $0,002(p>\alpha)$, yang berarti bahwa secara ststistik ada hubungan yang signifikan antara Sikap dengan Peran Kader Posyandu di Kecamatan 
Warunggunung. Nilai OR didapatkan, 5,375, dapat diartikan bahwa kader yang memiiliki sikap negatif berisiko 5 kali lebih besar memiliki peran serta yang kurang, dibandingkan dengan kader yang memiliki sikap positif.

Tabel 11

Hubungan Pengalaman dengan Peran Kader Posyandu di Kecamatan Warunggunung Tahun 2016

\begin{tabular}{lcccc}
\hline \multirow{2}{*}{ Pengalaman } & \multicolumn{2}{c}{ Peran } & \multirow{2}{*}{ Jumlah } & $\begin{array}{c}P \\
\text { Value }\end{array}$ \\
& Negatif & Positif & & \\
\hline$<10$ tahun & 13 & 23 & 36 & \\
\multirow{4}{*}{$\geq 10$ tahun } & $(36,1 \%)$ & $(63,9 \%)$ & $(100 \%)$ & \\
& $\begin{array}{c}7 \\
(17,9 \%)\end{array}$ & $\begin{array}{c}32 \\
(82,1 \%)\end{array}$ & $\begin{array}{c}39 \\
(100 \%)\end{array}$ & \multirow{2}{*}{0,076} \\
\cline { 1 - 4 } Jumlah & $\begin{array}{c}20 \\
(26,7 \%)\end{array}$ & $\begin{array}{c}55 \\
(73.3 \%)\end{array}$ & $\begin{array}{c}75 \\
(100 \%)\end{array}$ & \\
\hline
\end{tabular}

Dari tabel 4.11 diatas menunjukan bahwa kader yang memiliki peran negatif proporsinya lebih besar pada kader yang pengalamannya $<10$ tahun $\quad(36,1 \%)$ dibandingkan kader yang memiliki pengalaman $\geq 10$ tahun $(17,9 \%)$.

Hasil uji ststistik dengan menggunakan chi square pada alpha 0,05 diperoleh nilai $0,076(p>\alpha)$, yang berarti bahwa secara ststistik tidak ada hubungan yang signifikan antara Pengalaman dengan Peran Kader Posyandu di Kecamatan Warunggunung.

\section{Pembahasan}

1. Peran serta Kader Posyandu

Sesuai dengan hasil analisis univariat bahwa peran serta kader Posyandu di
Kecamatan Warunggunung tahun 2016 didapatkan hasil menunjukkan bahwa masih ada sebagian kecil Peran Serta Kader Posyandu kurang $(26,7 \%)$

Menurut Kamus Webster 1971 dalam Notoatmodjo (2005) mendefinisikan peran serta/pertisipasi sebagai kegiatan untuk mengambil bagian atau ikut menangung bersama dengan orang lain. Kader dapat berperan serta dalam siap antar jaga kesehatan ibu dan anak yaitu siap dan menjaga apabila ada ibu atau anak yang memerlukan pertolongan tenaga kesehatan. Peran kader dalam kasus ibu hamil dengan faktor risiko adalah dapat mengenal faktor risiko, menjelaskan kepada ibu/keluarga unutk melakukan pemeriksaan kehamilan serta merujuk ibu hamil dengan faktor risiko (Depkes RI, 2007).

Dari hasil penelitian ini diperoleh informasi bahwa sebagian besar kader posyandu tingkat pendidikannya rendah $(65,3 \%)$, hal ini juga berpengaruh terhadap pengetahuan kader tentang deteksi dini kehamilan dimana hampir setengahnya $(46,7)$ berpengetahuan kurang, disamping itu dipengaruhi oleh pengalaman dimana hampir setengahnya (48\%) pengalaman kader masih kurang.

Peran sebagai seorang kader sangatlah penting dibandingkan dengan masyarakat biasa pada umumnya. Seorang kader adalah relawan dari masyarakat 
setempat yang dipandang memiliki cukup pengaruh terhadap lingkungan masyarakat setempat dan dianggap mampu memberikan pelayanan kesehatan. Namun keberadaan kader kesehatan relatif labil karena tidak adanya jaminan kader akan dapat menjalankan fungsinya dengan baik. Jika ada kepentingan keluarga, maka kader biasanya akan lebih mendahulukan kepentingan pribadinya atau akan lebih memilih untuk meninggalkan tugas (Wulandari,2011).

1. Hubungan Pengetahuan dengan Peran Kader Posyandu

Hasil Penelitian menunjukkan bahwa kader yang memiliki pengetahuan kurang proporsinya lebih besar pada kader yang memiliki peran negatif $(40,0 \%)$ dibandingkan kader yang memiliki pengetahuan baik (15,0\%). Hasil uji ststistik dengan menggunakan chi square pada alpha 0,05 diperoleh nilai 0,015 ( $\mathrm{p}>$ $\alpha$ ), yang berarti bahwa secara ststistik ada hubungan yang signifikan antara Pengetahuan dengan Peran Kader Posyandu di Kecamatan Warunggunung. Dengan nilai OR 3,77 yang berarti bahwa kader yang memiliki pengetahuan kurang berisiko hampir 4 kali memiliki peran yang kurang sebagai kader posyandu, dibandingkan dengan kader yang memiliki pengetahuan baik.
Hasil Penelitian ini sesuai hasil penelitian Nugroho dan Nurdiana (2007) dimana ada hubungan antara pengetahuan dengan keaktifan kader posyandu dan didukung dengan hasil penelitian Ida Bagus dkk. (2014) terdapat hubungan yang cukup kuat antara pengetahuan dan dukungan keluarga dengan peran kader dalam pencapaian UCI kelurahan.

Salah satu hambatan kader dalam melakukan deteksi dini risiko tinggi pada ibu hamil adalah kader masih belum banyak mendapatkan informasi /pelatihan tentang bahaya risti pada bumil secara detail, oleh karena itu upaya yang dapat dilakukan dalam mengatasi masalah tersebut diatas meningkatkan pengetahuan kader melalui pelatihan khusus tentang deteksi dini risiko tinggi kehamilan. Sesuai dengan teori determinan perilaku oleh Green dalam Notoatdmojo (2012) yang menyebutkan bahwa salah satu terbentuknya perilaku seseorang dikarenakan oleh pengetahuan seseorang mengenai suatu subyek. Pengetahuan merupakan salah satu faktor predisposisi atau faktor pencetus seseorang untuk berperilaku. Rosphita (2007) dan Djuhaeni dkk (2010) menyatakan bahwa dari beberapa penelitian yang terkait mengenai hubungan antara pengetahuan dengan perilaku seseorang didapatkan hasil bahwa perilaku yang dilakukan dengan dasar 
pengetahuan akan lebih bertahan lama dibandingkan dengan perilaku yang tidak didasari oleh pengetahuan atau atas dasar keterpaksaan.

Dari hasil uraian diatas menunjukkan bahwa responden tidak paham deteksi dini faktor risiko kehamilan apa saja yang harus ditemukan dilihat banyaknya responden yang tidak mengetahui kriteria ibu hamil yang memiliki faktor risiko kehamilan.

2. Hubungan Pendidikan dengan Peran Kader Posyandu

Hasil Peneilitian menunjukkan kader yang memiliki peran negatif proporsinya lebih besar $(52,2 \%)$ pada kader yang tidak pernah pelatihan dibandingkan kader yang pernah mengikuti pelatihan $(15,4 \%)$. Hasil uji ststistik dengan menggunakan chi square pada alpha 0,05 diperoleh nilai $0,257(p>\alpha)$, yang berarti bahwa secara ststistik tidak ada hubungan yang signifikan antara Pendidikan dengan Peran Kader Posyandu di Kecamatan Warunggunung.

Hasil penelitian ini didukung dengan hasil penelitian Gusriyanti (2009) yang menyatakan bahwa tidak ada hubungan antara tingkat pendidikan dengan peranserta kader posyandu. Dan hasil penelitian Zulkarnain (2012) tidak ada hubungan antara pendidikan dengan peranserta kader posyandu.

Pada penelitian diatas menunjukkan bahwa tingginya tingkat pendidikan tidak berpengaruh terhadap peranserta kader posyandu walaupun tingkat pendidikan kader posyandu rendah tetap mempunyai peranserta tinggi, dikarenakan umumnya kader yang ditunjuk oleh masyarakat yang memiliki kepedulian yang besar dan dapat dipercaya untuk membangun kesehatan diwilayahnya. Dan pada umunya kader kesehatan adalah perempuan, dimana perempuan memiliki kepedulian dan tanggung jawab yang besar akan kesehatan dirinya, anak-anaknya dan masyarakat sekitarnya.

3. Hubungan Sikap dengan Peran Kader Posyandu

Sikap merupakan reaksi atau respon seseorang yang masih tertutup terhadap suatu stimulus atau objek. Manifestasi sikap tidak dapat langsung dilihat tetapi hanya dapat ditafsirkan terlebih dahulu dari perilaku yang tertutup. Sikap secara nyata menunjukkan konotasi adanya kesesuaian reaksi terhadap stimulus tertentu yang dalam kehidupan sehari-hari merupakan reaksi yang bersifat emosional terhadap stimulus sosial (Notoatmodjo, 2007).

Hasil penelitian menunjukkan bahwa kader yang memiliki peran negatif proporsinya lebih besar pada kader yang 
memiliki sikap kurang (50,0\%) dibandingkan kader yang memiliki sikap yang baik $(15,7 \%)$.

Hasil uji ststistik dengan menggunakan chi square pada alpha 0,05 diperoleh nilai $0,002(p>\alpha)$, yang berarti bahwa secara ststistik ada hubungan yang signifikan antara Sikap dengan Peran Kader Posyandu di Kecamatan Warunggunung. Nilai OR didapatkan, 5,375, dapat diartikan bahwa kader yang memiiliki sikap negatif berisiko 5 kali lebih besar memiliki peran serta yang kurang, dibandingkan dengan kader yang memiliki sikap positif.

Hasil penelitian ini sejalan dengan hasil penelitian Tri Tunggal dkk. (2013) dimana ada hubungan antara sikap dengan deteksi dini faktor risiko kehamilan oleh kader di wilayah kerja Puskesmas Kotabaru Kabupaten Kotabaru. Sikap mempengaruhi kesadaran responden terhadap deteksi dini faktor risiko kehamilan, kader kesehatan yang memiliki sikap postif akan memiliki kesadaran yang lebih tinggi untuk melakukan deteksi dini faktor risiko kehamilan.

Kader merupakan orang terdekat di masyarakat dan kader tidak memiliki kesibukan bekerja, kader mampu memiliki waktu luang di masyarakat. Kader yang memiliki kedekatan dengan masyarakat karena pengaruh aspek emosional sehingga akan memiliki kesadaran untuk bersikap positif.

4. Hubungan Pengalaman menjadi kader dengan Peran Kader Posyandu

Hasil penelitian menunjukan bahwa kader yang memiliki peran negatif proporsinya lebih besar pada kader yang pengalamannya $<10$ tahun $(36,1 \%)$ dibandingkan kader yang memiliki pengalaman $\geq 10$ tahun $(17,9 \%)$.

Hasil uji ststistik dengan menggunakan chi square pada alpha 0,05 diperoleh nilai $0,076(\mathrm{p}>\alpha)$, yang berarti bahwa secara ststistik tidak ada hubungan yang signifikan antara Pengalaman dengan Peran Kader Posyandu di Kecamatan Warunggunung.

Hal ini tidak sesuai sesuai dengan hasil penelitian Cholis (2011), dimana ada hubungan antara pengalaman dengan peran kader dalam mendeteksi dini resiko tinggi kehamilan

Pengalaman berkaitan dengan peran seseorang sesuai tugasnya di masyarakat salah satunya adalah berperan serta dalam melakukan pendeteksian adanya faktor risiko pada awal kehamilan, artinya semakin lama seseorang bekerja dalam organisasi semakin tinggi pula peran sertanya dalam organisasi tersebut. Hal itu terjadi karena ia semakin berpengalaman dan meningkatkan keterampilannya dalam 
melakukan deteksi dini faktor risiko kehamilan (Effendi, 2009).

$$
\text { Seseorang yang memiliki }
$$

pengalaman lebih banyak tentang skrining antenatal maka semakin baik dalam melakukan deteksi dini risiko kehamilan, hal ini dapat dilihat dari berapa lama orang tersebut berkarya didalam pekerjaannya. Untuk meningkatkan pengalaman kader dalam deteksi dini risiko kehamilan adalah dengan cara selalu aktif dalam melakukan deteksi dini risiko kehamilan.

\section{Simpulan}

1. Masih ada sebagian kecil Peran Serta Kader Posyandu kurang (26,7\%).

2. Hampir setengahnya Pengetahuan Kader Posyandu kurang $(45,3)$.

3. Sebagian besar kader posyandu tingkat pendidikannya rendah $(65,3 \%)$.

4. Masih ada sebagian kecil kader posyandu tidak pernah mengikuti pelatihan kader $(30,7 \%)$.

5. Masih terdapat kader posyandu bersikap negatif terhadap deteksi dini pada kehamilan $(32,0 \%)$.

6. Hampir setengahnya kader posyandu pengalaman menjadi kader $<10$ tahun $(48,0 \%)$.

7. Terdapat Hubungan antara Pengetahuan, Sikap dan Riwayat Pelatihan dengan Peran Kader
Posyandu di Kecamatan Warunggunung.

8. Tidak terdapat hubungan antara, Pendidikan dan Pengalaman dengan Peran Kader Posyandu di Kecamatan Warunggunung.

\section{Daftar Pustaka}

Arini. 2012. Mengapa Seorang Ibu Harus Menyusui. Jakarta : Fleshbook

Dian, K. 2007. Peran Serta Kader. http://www.skrining.com. Diakses pada tanggal 25 Juli 2011.

Dinas Kesehatan Kabupaten lebak, 2015, Profil Kesehatan Kabupaten Lebak tahun 2015, Dinkes Kabupaten Lebak

Effendi, Ferry dan Makhfudli. 2009. Keperawatan Kesehatan Komunitas Teori dan Praktik dalam Keperawatan.Jakarta : Salemba Medika.

Hidayat, Aziz A. 2010. Metode Penelitian Kebidanan dan Teknik Analisis Data. Jakarta : Salemba Medika.

Ida Bagus Made Dwi Indrawan, Chatarina Umbul W. 2014 Hubungan Pengetahuan Serta Dukungan 
Keluarga Dengan Peran Kader

Dalam Pencapaian Uci Kelurahan,

Jurnal Berkala Epidemiologi, Volume

2 Nomor 1, Januari 2014, hlm. 83-92.

Unair Surabaya.

Notoatmodjo, Soekidjo, 2003, Pendidikan

dan Perilaku Kesehatan, PT Rineka

Cipta, Jakarta

2003. Metode

Penelitian Kesehatan.: PT. Rineka Cipta Jakarta.

2012. Promosi

Kesehatan dan Perilaku Kesehatan.

Rineka Cipta. Jakarta

Nugroho Adi Haryanto, Nurdiana Dewi (2008), Hubungan Antara Pengetahuan Dan Motivasi Kader Posyandu Dengan Keaktifan Kader Posyandu Di Desa Dukuh Tengah Kecamatan Ketanggungaii Kabupaten Brebes. Jurnal Keperawatan.

Pinem, S , 2010. Kesehatan Reproduksi dan Kontrasepsi. Jakarta : Trans Info Media
Puskesmas Warungunung, Laporan kegiatan KIA tahun 2015

Robbin SP. 2002. Organizational Behaviour:Concept, Controvercies, Aplications. Edisi Ke-8. New York : Prentice Hall Inc

Rosphita. 2007. Faktor - Faktor yang Berhubungan Dengan Keterampilan Kader dalam Menginterpretasikan Hasil Penimbangan ( $N$ dan $T$ ) dalam KMS di Puskesmas Baumata Kabupaten Kupang. Jurnal Gizi. Yogyakarta; Universitas Gadjah Mada

Sugeng. 2008. Faktor-faktor Yang Mempengaruhi Keaktifan Kader Dalam Deteksi risiko Kehamilan (Online), (http://one.indoskripsi.com. Diakses pada tanggal 20 April 2016

Sugiyono. 2010. Statistika untuk Penelitian. Bandung :Alfabeta

Siswanto. 2002. Faktor-Faktor YangMempengaruhi Peran Serta Kader Dalam Deteksi Dini Risiko Kehamilan. 
Wulandari, R,A. 2011.Faktor yang berhubungan dengan Keaktifan kader Posyandu dalam menunjang keberhasilan pencapaian tingkat partisipasi masyarakat.Skripsi.

Surabaya; Universitas Airlangga 